\title{
Ethics into Practice: Holding Paramount Health, Safety \& Welfare of the Public by Entrepreneurial Engineers in Sri Lanka
}

\author{
D.P.S. Wijesinghe, V.P.T. Jayawardane and S.W.S.B. Dasanayake
}

\begin{abstract}
Advent of more and more entrepreneurial firms by engineers is an essential requirement for the economic development of Sri Lanka. Nowadays, many innovative minded engineers have started up their business ventures rather than practising as traditional employees. Although they are running their ventures, they cannot take off their engineering hat. They are always professional engineers and should adhere to Engineering Ethics, although they perform as business leaders. This research aims to identify how techno-entrepreneurial engineers hold paramount health, safety and welfare of the public during their entrepreneurial functions as a way of fulfilling their ethical responsibility. Based on an ongoing grounded theory study, in which data have been collected by holding in-depth interviews with ten chartered engineers working as techno-entrepreneurs in Sri Lanka, the research establishes three significant categories of practices as individual, firm-level and community-oriented practices to hold paramount the health, safety, and welfare. Investigations into their company websites too, reinforced the above findings. Holding paramount health, safety, and welfare of the public has positively strengthened entrepreneurial behaviour in long-term perspectives. During a time where entrepreneurship has been fostered in the country to accelerate economic development, this study glimpses the entrepreneurial engineers in Sri Lanka who have not been studied significantly yet.
\end{abstract}

Keywords: $\quad$ Engineering ethics, Entrepreneurial engineers, Health, Safety, Sri Lanka

\section{Introduction}

Engineers can be considered an essential group of human capital to foster the economic development of any country. As a stilldeveloping country, Sri Lanka should attempt to obtain the maximum contribution of engineers to bring the country to an economically developed stage. Many innovative minded engineers in Sri Lanka and in international context are running their business ventures making a huge contribution to the country's economic development as techno-entrepreneurs. Many well-known, lucrative, and billion-dollar technological businesses have been started up and run by professional engineers. For example, Reliance Ltd by Mr Mukesh Ambani, Telmex by $\mathrm{Mr}$ Carlos Slim, Google by Mr Larry Page, Koch industries by $\mathrm{Mr}$ Charles Koch, Facebook by $\mathrm{Mr}$ Mark Zuckerberg, and Amazon/Blue Origin by Mr Jeff Bezos can be identified [1].

In any context, ethical practices of technoentrepreneurial engineers are highly expected by society since they are dealing with innovative technologies. Such ethical practices should be investigated more deeply to make them available for emerging entrepreneurial engineers to adopt to gain success in their businesses in a shorter time. Hence, this research paper investigates the health and safety practices of Sri Lankan technoentrepreneurial engineers as per the requirement of the code of Engineering Ethics and its implications on entrepreneurial behaviour.
Eng. D.P.S. Wijesinghe, AMIE(SL), AEng., B.Sc. Eng.

(Hons) (Moratuwa), PhD student, Department of Industrial Management, University of Moratuwa,

Email:praneeth@is.ruh.ac.lk

(D) https://orcid.org/0000-0001-5746-9510

Eng. (Dr.) (Mrs). V.P.T. Jayawardane, AMIE(SL), AEng, B.Sc Eng (New Zealand), LLB(Hons)(London), MPhil, PhD, Senior Lecturer, Department of Industrial Management, University of Moratuwa.

Email:thesaraj@uom.lk

(iD) $h$ ttps://orcid.org/0000-0002-0493-114X

Prof. S.W.S.B. Dasanayake, BA (Hons), MA, PhD

(Netherland), Senior Professor in Management of

Technology, Department of Management of Technology,

University of Moratuwa.

Email:sarathd@uom.lk

(iD) https://orcid.org/0000-0002-1584-0673 


\section{Literature Review}

\subsection{Entrepreneurship}

Entrepreneurship is a commonly discussed research domain worldwide and has several scholarly definitions. Reference [2] has defined entrepreneurship as the "scholarly examination of how, by whom, and with what effects opportunities to create future goods and services are discovered, evaluated, and exploited". Another highly recognised definition has been given by the famous management consultant Drucker (1985), differently [3]. He has identified that "entrepreneurship is comprised of five parameters as creating new markets, delivering value to the customer, providing something new, changing customer value, and process innovation." Entrepreneurs demonstrate several behavioural characteristics that are unique to themselves. A review of the existing literature discloses important behavioural characteristics of entrepreneurs as internal locus of control, risk-taking, need for achievement, need for recognition, professional confidence, passion, opportunity-seeking, and need to serve society [4].

\subsection{Techno-Entrepreneurial Engineers}

Entrepreneurship has several scholarly domains, and technology entrepreneurship is an emerging research domain as a subdomain in entrepreneurship in Sri Lanka and in the international context. As per [5], "technology entrepreneurship is a style of business leadership that involves identifying highpotential, technology-intense commercial opportunities, gathering resources such as talent and capital, and managing rapid growth and significant risks using principled decisionmaking skills." Since engineers are the people who demonstrate expertise in engineering and technology, they tend to exploit technology intense commercial opportunities via their ventures. This tendency is valid for the Sri Lankan context as well, and it was further confirmed by recent research conducted by Thiranagama (2015) [4]. Although such entrepreneurial engineers practice as business leaders, they must demonstrate ethical practices as per the codes of Engineering Ethics.

\subsection{Engineering Ethics}

Principles referring to a fundamental and comprehensive morality regarding behaviour and conduct of engineers are known as codes of Engineering Ethics [6]. Many international professional engineering bodies like the
American Society of Professional Engineers (ASPE), the National Society of Professional Engineers (NSPE), and the Institution of Electrical \& Electronics Engineers (IEEE) have introduced their codes of conduct for their member engineers. Member engineers of the Institution of Engineers Sri Lanka (IESL) shall adhere to the code of ethics introduced by IESL to develop their moral conduct. Recently established the Engineering Council of Sri Lanka (ECSL) has also introduced a code of ethics for engineering practitioners in Sri Lanka. Most of the code of ethics for engineers consist of similar guidelines. Although entrepreneurial engineers work as owners of their technological business ventures, they introduce themselves as professional engineers to their clients and the general public. Therefore, entrepreneurial engineers also should adhere to Engineering Ethics in the techno-entrepreneurial business environments to uphold the professionalism of engineers.

\subsection{Health \& Safety}

Health and safety is the paramount important aspect of any task whether it is engineering or non-engineering, as the value of human life cannot be under-estimated. Hence, organisations have adopted the Occupational Health \& Safety Assessment Series (OHSAS) guidelines to ensure the health and safety of their employees, clients, and the general public. Research literature contains an ample amount of scholarly works related to the health and safety practices of different organisations worldwide. In the Sri Lankan context, there are also many research works carried out regarding the health \& safety of various work environments concerning OHSAS requirements [7][8]. A recent study conducted in Sri Lanka has identified that the adoption of health and safety practices by large scale industries has considerably been improved. In contrast, small and medium scale industries have not focused on health and safety significantly [9]. According to the codes of Engineering Ethics, the most important clause is the "Engineers shall hold paramount health, safety, and welfare of the public" [10]. Irrespective of OHSAS requirements, engineers have an ethical obligation to ensure health \& safety in their workplaces. However, nobody has inquired the commitment of entrepreneurial engineers to hold paramount the health, safety and welfare of the public within the perspective of Engineering Ethics in their entrepreneurial ventures. 


\section{Methodology}

This study was designed following the constructionist grounded theory methodology as qualitative research. For research domains investigating the different social phenomena that lack former systematic studies, qualitative research is highly recommended to commence such studies in-depth [11]. Ethical practices of entrepreneurial engineers have not yet been studied in the Sri Lankan context, and hence, the selection of qualitative research strategy can be justified. Rich, meaningful data were gathered by conducting in-depth face to face interviews with techno-entrepreneurial chartered engineers in Sri Lanka. Interviews were conducted in a meaningful manner by employing a semi-structured questionnaire [11]. The first author himself conducted the interviews by visiting the offices of the interviewees. Each interview lasted for nearly one hour and voice recorded with the consent of the interviewee. All the data gathered were handled and used confidentially so that the interviewees' identities are not revealed to anybody else other than the first author.

\subsection{Sample}

Random sampling is not a recommended sampling strategy for qualitative studies. Purposeful sampling is followed in the initial stages of the grounded theory studies by many scholars worldwide [11]. Purposeful sampling allows researchers to select interviewees who can provide meaningful insights regarding the research issue being investigated as per some pre-determined criteria. Hence, when selecting the interviewees for this study, the authors purposively selected chartered engineers running technology-related business ventures in Sri Lanka since chartered engineers have more knowledge on Engineering Ethics than any engineering practitioner in the society with the attainment of the charter qualification. It should be clearly understood that this study was conducted focusing only on the engineers who run their entrepreneurial firms, not on engineers who work in the private and public sector as employees. Sampling in qualitative studies does not require numerous participants like in quantitative studies, where sample is proportionate to the study population. Even though there are no regulations on the ideal number of participants for interviews, a number between four to ten participants is satisfactory and used widely by qualitative scholars [12]. Therefore, a purposive sample of ten techno-entrepreneurial chartered engineers was selected after getting their consent.

\subsection{Data Analysis}

Interview recordings were transcribed verbatim into MS word files within two-three days of the interview. Before starting the coding, data were triangulated by member checking [13]. Each entrepreneurial engineer was contacted via email with a copy of his interview transcription to allow them to make changes and corrections before the coding process started. However, nobody sent any comments or modifications to their transcripts confirming that they agree with their mentioned information during the interview. To identify significant categories in interview transcripts, both common and unique underlying the interviewees' views, the process of comparing and contrasting was utilised [14]. The analysis method used in this study is the initial stage of the grounded theory analysis with the support of the NVivo 12 Plus qualitative data analysis software [15]. Analysed data was presented to a few interview participants to check the accuracy of interpretations and further discussed with experts to achieve the rigour of this research [11], [15]. Interviews were conducted from time to time, starting from the year 2018. As specified in the grounded theory methodology, data analysis began at the end of each interview following the verbatim transcription [16]. The findings of each interview were further questioned with the next interviewees for better clarifications. Further, the content of their company websites was also analysed to find pieces of evidence that reinforce or make contradictions with the findings of this study.

\section{Results \& Discussion}

Interviewees were given pseudonyms as $\mathrm{A}, \mathrm{B}$, C, D, E, F, G, H, J and $\mathrm{K}$ to protect their confidentiality. Here onwards, each interviewee will be referred to as $\mathrm{A}, \mathrm{B}$, and so on in this text. A, B, C, D, E, F, H, J \& K are the founders of their techno-entrepreneurial firms and currently manage them as Managing Director (MD)/Chief Executive Officer (CEO) of their firms. At the same time, $G$ has taken the leadership of the particular firm, which was established by another person a few years ago. Currently, G can make his own decisions in the firm without consulting anybody. Their entrepreneurial experiences range from 5 years to 20 years as business leaders. Before stepping into entrepreneurship, they all have worked in the industry as employees to gain industrial 
exposure. They are running engineering-related consultancy and service providing firms belonging to the Small \& Medium Enterprise (SME) category. Their firms mainly operate in construction, structural engineering, chemical engineering, electrical engineering, and cybersecurity. The exact demographic information of each interviewee cannot be disclosed due to the greater possibility of recognising their identity by the readers.

Analysis of the data has established three major categories of strategies followed by interviewees to adhere to the most crucial clause in the code of ethics, i.e., Engineers shall hold paramount health, safety and welfare of the public in their entrepreneurial environment. Therefore, the following section discusses and interprets the most highlighted categories and factors supporting narrative evidence.

Table 1 - Major Categories of Strategies

\begin{tabular}{|l|l|}
\hline Main Category & Sub Categories \\
\hline $\begin{array}{l}\text { Individual } \\
\text { Commitment }\end{array}$ & $\begin{array}{l}\text { Prioritising health \& safety, } \\
\text { Minimising mistakes, Reducing profit } \\
\text { margins, Criticising malpractices }\end{array}$ \\
\hline Firm-Level & $\begin{array}{l}\text { Advising employees on health \& } \\
\text { safety, Facilitating knowledge } \\
\text { updating, Employing competent } \\
\text { people }\end{array}$ \\
\hline $\begin{array}{l}\text { Community } \\
\text { Outreach }\end{array}$ & $\begin{array}{l}\text { Always following standards, Not } \\
\text { introducing harmful things to the } \\
\text { society }\end{array}$ \\
\hline
\end{tabular}

\subsection{Individual Commitment}

Entrepreneurs as leaders in their business should demonstrate their commitment towards creating a healthy and safe work environment for their employees and the public. If they are not showing their passion for developing such organisational culture, their employees will not work for that. Attitudes towards health and safety are instrumental in influencing the intentions to achieve the same in small business firms [17]. Techno-entrepreneurial engineers who had participated in the interviews have demonstrated their passion for holding paramount health, safety, and welfare with the influence of the code of ethics.

All interviewees have exhibited their commitment to giving priority to health and safety within the business operations. A has commented as "the supreme profit of any project is the health of mankind and the rest of the ecosystem. Because the rest of the ecosystem is not healthy, automatically mankind dies." It confirms that $\mathrm{A}$ is of the view that the utmost outcome of any project should be the health of the human being. Projects should be implemented while doing lesser damage to the ecosystems since polluted ecosystems also negatively affect the health of human beings. Religious beliefs also have shaped A's view on health \& safety. A has further emphasised: "In any developing project engineer should ethically know, main profit should be the health. Then another term in Buddhism called "Arogya Parama Laabha" There is another verse in the same sutra preached to a particular king as "Santhusti Paraman Dhanan". That the profit should be the happiness of the people."

Reference [18] also argues that different religious beliefs can make different levels of value propositions to the meaning of clause number one in the code of ethics. B has added his concern as "We have a responsibility towards the safety of our projects. If we have that concern, we can work in different fields." He has further emphasised it as, "You know that, in chemical engineering, chemical reactions are frequent in chemical product manufacturing. So, safety is very much important. From my employees to my customers, I should ensure safety. I pay much attention to that." Understanding the severity of their deliverables and ensuring the safety among all stakeholders can be identified as an essential quality of an entrepreneurial engineer as an expert in the particular technology. As an entrepreneurial engineer who runs his consultancy firm, D has expressed his opinion as "So, the consultant has a role in ensuring that the health and safety are established at construction sites. Because in our offices, of course, it is not a major thing." As a consultant engineer, D believes he has an ethical responsibility to uphold health and safety practices in the construction sites. Nowadays, there are many safety issues in various construction sites in Sri Lanka [19] and require the support of all stakeholders to ensure health and safety.

Further to [19], similar research has also identified that Sri Lankan construction companies have very little risk awareness and do not consider health and safety necessary [20]. Therefore, as a consultant engineer, D's intention is praiseworthy to uplift health and safety in construction sites. D has further elaborated his commitment as "I always recommend that if you are doing a high rise building, that it should be reviewed by an external party. We do it in all our high rise building projects, and we always ask reputed foreign parties to review our designs." D is recommending doing additional reviews for structural consultancy works done by his firm without considering the expense of extra time and money to ensure 
safety further, although it is not a mandatory requirement.

As a consultant engineer in the highway and transportation sector who runs his own consultancy firm, C does not involve in consultancy works where he lacks expertise. C has emphasised his policy as "Even if somebody asks me to do a bridge, I might say no because that is not my area. Roads and bridges are not my areas. So I will not do it." It is because to ensure health and safety. Because he knows that if he involves in a project in which he lacks experience and expertise, there is a greater possibility of mistakes from his side. Since he does not want to expose clients and the public to unnecessary danger, hence his decision. It was also found from his company website that his company vision statement focused on enhancing everyone's lifestyle, truly satisfying and convincing beyond focusing on the welfare of the public.

F has also confirmed that approach as "Can you do something that you are not aware of? Not frequently doing? If you are specialised in some engineering discipline, you should follow that discipline because you have ample experience related to that field, but not to the other fields, such fields you are touching only." Practising only in the specialised area is recommended in most engineering code of ethics for practising engineers [21]. C \& F are strictly adhering to hold paramount health, safety, and welfare as entrepreneurial engineers. Narratives extracted from the interview transcripts mentioned above demonstrate how entrepreneurial engineers prioritise health and safety, exhibiting individual commitment.

All engineers should try to minimise mistakes happening from their side [21]. Entrepreneurial engineers have identified that always attempting to minimise mistakes is a better strategy to hold paramount health, safety, and welfare. Five out of eight interviewees have demonstrated that as an individual commitment. D has expressed his opinion on mistakes as "We are human beings and can make mistakes. You cannot say I am a senior structural engineer; I will never make mistakes. That is a wrong statement because we are human beings and can make mistakes. Doing a proper review, proper review, I mean we are getting an extra certificate." Making mistakes is human nature. However, it is not an excuse to make mistakes consistently and endanger the lives of the public. As an owner of a leading structural engineering consultancy firm, D believes that proper review will reduce the mistakes happening from their side. That is a strategy followed in his firm with his commitment. F has mentioned his commitment in this regard as "We always analyse it. We normally do not provide design, detail or whatever the work quickly. We do some research, and we find details, we analyse it, then provide our solutions, that is multiple approaches." F and his team follow multiple approaches to deliver any project without mistakes. It is not an easy task and takes time, money, and effort. F has further emphasised that "We cannot harm the project. The bad thing is if we harm the project. Even if we get something wrong or there may be many mistakes or something like that can be happening. It is normal in nature. But even then, once you find it, you should correct it at that moment." Avoidance of mistakes is a paramount important aspect. Similarly, as techno entrepreneurial engineers, acceptance of mistakes and correcting them is also an essential aspect for ensuring the health and safety of the public [5]. As a technoentrepreneurial engineer in the cyber-security field, G has mentioned, "Therefore every time we are doing things, we have to make sure there are no mistakes. But there can be mistakes. But at the same time, there are some incidents like we have missed because all are human and also I am, and all the seniors are not looking after every customer, there are junior engineers as well. They can make mistakes because we also have made mistakes in our life, then actually what we do is we admit that we are not going to respond saying these are not our faults, we are not bypassing them". G has mentioned his commitment to reducing mistakes and correcting them if there are such. If these entrepreneurial engineers do not demonstrate their commitment to reducing mistakes, they cannot expect the same from their subordinates. Moreover, investigations into G's company website revealed that his company's mission statement is to ensure the information security of institutions and the general public and safeguard them from cyber-attacks. This is an emerging scenario in the Sri Lankan technological paradigm where information safety becomes critical and needs to be assured.

Profit is a critical success factor for any entrepreneur [5]. However, technoentrepreneurial engineers like $B, D, F$, and $H$ have followed different practices to hold paramount health, safety, and welfare of the public. Eventually, such practices have led to the reduction of their profit margins. B has said, "I follow a rigorous testing process before launching any chemical product into the market. Although it seems costly, it is a practice in my company". 
Knowing the severity of the chemical products manufactured in his company, B is doing costly testing procedures. It affects the overall profit of his company. However, that approach has allowed him to release the chemical products with a satisfactory confidence level about their safety. D also has a practice, which badly affects the profit margins of his entrepreneurial firm. D has explained his practice as "Doing a proper review, proper review I mean we are getting an extra certificate. And you also feel very comfortable, and client also feels very comfortable when we have extra checking." Extra checking costs money, time and effort of the employees or for a third party, which can be spent on another project. Because of the ethical considerations on ensuring safety, they are doing that. $\mathrm{F}$ has also supported this claim differently, "We send the people for training. So we know that when they train only we will get something and they will get something. That expense is not a big thing since we gain something." If employees are getting proper education and training regarding their works, they will not blindly involve in unsafe practices [22]. Whether the training programs are on safety or technical matters, they will cost money. It reduces the profit margins of entrepreneurial firms. $F$ is of the opinion that it is not a considerable expense as it gives long-term benefits to the firm. $\mathrm{H}$, as an entrepreneurial engineer in the environmental sector, also is working with low-profit margins. He has explained it as, "As well as we try to reduce our margins. Because clients try to do something for the environment. Especially in high tech installations, we are going with only a little margin". Hence, $\mathrm{H}$ is helping his clients install high tech water treatment plants in their firms while maintaining lower profit margins, as such initiations help ensure the public's health, safety, and welfare. Entrepreneurial engineers work in low-profit margins with the expectation to hold paramount the health, safety, and welfare of the public.

\subsection{Firm-level Strategies}

Analysis of the interview transcripts revealed that techno-entrepreneurial chartered engineers follow different strategies to hold paramount health, safety, and welfare of the public at their firm level with the support of their employees. Here, techno-entrepreneurial engineers work collaboratively with their subordinates to enhance health and safety factors.

They advise and guide their employees regarding the requirements to ensure health and safety. As a leading entrepreneurial engineer in the chemical industry, B has said, "Although we have the good technical knowledge, our workers do not have such knowledge. So, we have to educate them regarding our works and safety. It is essential. Normally, our labourers are not educated. We have to change them based on our business requirements". He is concerned about his uneducated labourers who do not have sufficient knowledge of technical matters and safety practices. As an experienced and responsible engineer, $\mathrm{B}$ has taken actions to advise his shop floor level employees. In the context where lesser awareness and education is delivered to employees [19], B's approach is significant for the entire field. $\mathrm{H}$ has mentioned, "We always think safety precautions with workers also, we always ask them to use safety precautions". $\mathrm{H}^{\prime} \mathrm{s}$ employees are installing mechanical equipment. Hence, safety precautions are essential for his employees. Therefore, $\mathrm{H}$ is always asking his employees to take the necessary safety precautions to ensure the health and safety themselves. Taking necessary safety precautions for the employees is highly recommended in OSH management. The code of ethics strengthens $\mathrm{OSH}$ practices further. Narratives of $\mathrm{D} \& \mathrm{H}$ are good pieces of evidence to show that they have taken initiatives to educate their employees regarding safety in a situation where the Sri Lankan construction industry lacks such practices [7]. F has advised his employees regarding the mistakes as follows. "We do not train our people like that; we tell them if you find mistakes later on or at the very later stage even, you can correct it, or whatever correction measure should take." Not only the entrepreneurial engineer himself is involved with correcting mistakes. That practice also should progress with its employees. Hence, such clear guidance is necessary to reduce the health and safety hazards associated with the mistakes in engineering \& technology.

Another vital strategy identified at the firm level is facilitating the knowledge updating process of the employees. Technology is changing day by day, and hence updated knowledge is essential for any practitioner in engineering and technology [5]. Similar to giving training and education in the safety domain for the employees as identified in [19], working with updated knowledge can be identified as one way of holding paramount health, safety, and welfare of the public since practising with the latest knowledge will reduce the possibility of the occurrence of health and safety hazards. D has explained it as 
"I strongly believe that updating the knowledge is paramount important for engineers. If you are not going to update your knowledge, you will become outdated. If I do not know to study, now, at this age to see what are the developments, I should retire." E has recommended the same as follows. "Even the technology is changing, systems are changing, so it is a must. If you don't understand the next generation things, if you don't develop, you will be a dinosaur". As entrepreneurial engineers, they know the significance of working with updated knowledge. That approach has allowed them to survive in the business field with safer practices. $\mathrm{H}$ is arranging various training sessions for himself and his staff when there is such a requirement. $\mathrm{H}$ has explained his approach as "If my knowledge is not enough, I just call my supplier and get a training session or like that. If not ask them to come here at the installation stage, and also we improve our knowledge like that". Engineers have an ethical responsibility to enhance their own and their subordinates' professional knowledge throughout their life [10]. That responsibility directly affects achieving health, safety, and welfare of the public as updated knowledge on technical matters and safety practices will further ensure health and safety. Likewise, technoentrepreneurial chartered engineers in Sri Lanka facilitate the knowledge updating process of themselves and their employees.

Furthermore, techno-entrepreneurial engineers employ competent employees for areas in which they lack expertise. Performing professional services only in specialised areas is a clause included in the IESL code of ethics [10]. That is included in many of the codes of ethics with the expectation of holding paramount health, safety, and welfare of the public [21]. Employing competent and expert people in their entrepreneurial firms can be identified as one of the strategies they follow to ensure the health and safety of the clients and the public within their firm level. $\mathrm{C}$ has explained his practice as "You know that person who is knowledgeable, he can do that and can do the right thing, and the user is benefitted by safety, economics, financial and everything if you are doing the things correctly". According to the above narrative, $C$ has identified that only the expert people can deliver things accurately with higher safety, economic, and financial gains. Therefore, people who are specialised in a particular area should be employed in entrepreneurial firms to balance safety and economic aspects. $C$ has further emphasised it as "We recruit the correct persons when we have the qualified persons only, we will do it. I cannot ask my civil engineers to do some electrical or plumbing or something". F has also revealed the same practice as "We have competent people for each and every segment which we are doing. All chartered engineers". F is getting the assistance of chartered engineers specialised in relevant disciplines when delivering services from his techno-entrepreneurial firm. Professionals like engineers who have become experts in different specialised areas by education and experience know about the safety and health issues of their works better than anybody else [21]. D has explained his practice in this regard as "you know especially, we have to understand who we are, you are specialised in one field. So you should not provide services in the other areas - those things we strictly maintain. As a consultant structural engineer, he strictly adheres to practising only in the specialised area. Further, D has mentioned, "So, like from the beginning, you have to work with other consultants. I am actually sharing, getting advice from other consultants. Even for a small job you can do that." D is sharing knowledge and getting advice from other consultants in the field when delivering his services. This collaborative approach ensures the delivery of safe products, designs, and services as they can discuss such matters with experts. At firm level, techno-entrepreneurial chartered engineers follow the abovementioned strategies directly or indirectly to hold paramount health, safety, and welfare of the public.

\subsection{Community Outreach}

Entrepreneurial engineers should maintain a healthy and safer relationship with the community (clients and public) since the community uses their final products and services. Interviewees have followed different strategies to accomplish the $1^{\text {st }}$ clause of the code of ethics when dealing with the community. In this section, a few strategies that emerged from the interview transcripts of the techno-entrepreneurial chartered engineers are discussed.

The majority of the interviewees have mentioned that they always follow the applicable standards when delivering products, designs, and services to the clients/community from their entrepreneurial firms to assure safety. Practising engineers should deliver their products/services following the engineering and other standards accepted in the country without working on their own agendas. Experts have developed standards in the relevant fields, incorporating the best practices in the industry 
modified over time. E has mentioned his practice as follows. "Generally, when we do the design, one portion anyway covers our guidelines or codes, most of the things get covered. Because we cannot do a design that will collapse next month". He knows that if designs are done following the applicable standards, a significant portion of its safety issues has got solved. As mentioned on the company website, the Corporate value statements of E's company also reveals the position he has given for safety in his business operations. It was highlighted that his company has a responsibility towards the safety of their staff and the constructors and users of the designs. As highlighted in [20], the incorporation of safety concerns in the company policies is essential to ensure health and safety.

F has also recommended the same, as "we should maintain our proper engineering practices. All these engineering practices are made standards for the safety of the public, right? Once we follow that, when we put our time into that, we will design our works or whatever our services align with these standards. In return, you will get the safety and upholding and all these factors." $\mathrm{F}$ has further elaborated his approach with clients and the public as "Normally we advise what to do and it governs through the standards. If it is not to the standards, we do not do that. If the client violates the standards, then we are not allowing, or we are not doing that." As per the narratives of $\mathrm{F}$, it is clear that he is refusing the clients who are asking for designs and services which violate applicable standards. Sometimes, clients request from engineers designs and services in the business field that deviate from the relevant standards due to different reasons. Clients urge consultant engineers to proceed with such deviations claiming that they can pay whatever the consultancy firm requires. However, $\mathrm{F}$ is not proceeding with such clients who ask him to violate relevant standards, although he loses businesses. $\mathrm{D}$ is advising his subordinates regarding adherence to standards to ensure safety and deliver safe products to society. "I always think, prefer and advise our young engineers. Also, whatever you do, you have to follow proper procedures and standards to ensure the safety of the public." Employees of techno-entrepreneurial firms should be guided appropriately as D is doing, expecting the same ethical behaviour as the firm's owner. B has recommended, "What I observe is we have to work according to the applicable legal regulations in the country. If you are doing construction works, you should follow ICTAD regulations and so on..." As per the narrative of $\mathrm{B}$, adherence to legal regulations is also crucial as adherence to applicable engineering standards when performing engineering-related works through the techno-entrepreneurial firms.

In the business arena, entrepreneurs tend to exploit whatever opportunities which make a profit for themselves without considering much about the harmful effects of such opportunities for the public at the start-up stage of the firms. However, most of the interviewees have mentioned in their interviews that they are trying not to introduce any harmful things to the public as entrepreneurial engineers. B has mentioned, "As a professional engineer, I am always considering the safe usage of the chemical products I supply for different projects." Industrial chemicals are not $100 \%$ safe to use. However, B introduces such things to society with proper guidelines after following rigorous testing procedures to enhance safe usage. E has said. "What we are going to do is not good for society, Right? So, those things we do not follow. So, whatever may be a big loss for us, but still, we say 'No'. That we maintain." $\mathrm{E}$ and the team have decided not to involve delivering any harmful products or designs to the community, affecting safety. As an entrepreneurial engineer in the cybersecurity field, G mentioned, "we do not just take that technology and try to push it here. Then we change it based on Sri Lankan companies' capabilities and technologies." Technical products available in foreign countries may not be suitable for the Sri Lankan context in some aspects. Therefore, G is not simply introducing foreign products to the Sri Lankan market as it is. $G$ and his team modify such products to suit the Sri Lankan context to reduce harmful effects. G has further emphasised, "We show them, we prove them about the capability of the product or the service we are going to offer them." As per the narrative of $G$, he gives the full details of the products to their clients, and upon the satisfaction of the client, he supplies such products to them. As an entrepreneurial engineer in the wastewater treatment sector, $\mathrm{H}$ has explained his opinion as "In our field actually we cannot introduce harmful things. That is why I said earlier also, and we have to think about wastewater reuse. That is a major concern. That is why we use high tech things." In H's field, harmful things cannot be introduced to the community. However, his products should ensure that they carry out the intended purpose. That is the reason why $\mathrm{H}$ is introducing high tech products to the community. Selected narratives mentioned above clearly demonstrate that interviewees are in a mindset of not introducing harmful things to the community. 


\section{4}

\section{Implications for Entrepreneurial Behaviour}

Entrepreneurs demonstrate different behavioural characteristics throughout their entrepreneurial journey. Risk-taking, need for achievement, internal locus of control, professional confidence, passion, need for recognition, need to serve society, and opportunity-seeking can be identified as major behavioural characteristics of entrepreneurs throughout the world [3]-[5]. This study has revealed that techno-entrepreneurial engineers who participated in in-depth interviews have experienced both positive and negative implications on their entrepreneurial behaviour to adhere to the first clause of the code of ethics during their business activities. The risk-taking behaviour of entrepreneurial engineers was affected by this clause of the code of ethics since entrepreneurial engineers were reluctant to introduce novel products to society whose side effects were not identified completely. Engineer $\mathrm{J}$, who works with innovative designs, takes the risk and introduce the same to his client. However, sometimes J had to pay back his clients when those innovative designs go erroneous considering the welfare of the client and public. J highlighted, "If something goes wrong, if in case one of our innovative things does not work, it will be bad; actually, it is a risk. Risk in the sense we have to take the responsibility sometimes will have to pay the client back. For that kind of things, we take the risk. But we consider it as a kind of challenge."

Similarly, they employ only the experts or competent human capital to deliver their products/services without doing trial and error. Their need for achievement behaviour, as explained by the McClelland's needs theory [23], is also affected in both positive and negative ways. Their profit margins are not at higher levels since they have to pay higher salaries for the expert people in the relevant fields. At times, they cannot move to other practising areas without getting the support of such expertise. They shall hold paramount health, safety, and welfare of the public while balancing their business continuity. Therefore, they cannot diversify their businesses quickly in such an environment. In the short term most techno-entrepreneurial engineers cannot achieve their expectations like higher profits, market expansions, etc. For example, techno entrepreneurial engineers like $B$ and $D$ are doing rigorous testing and review processes for their products and designs to ensure safety. Such efforts are costly and consume the time of their employees. Similarly, E is not working with any client who urges him to violate applicable standards. Because of that, E is losing many business opportunities. J also highlighted the same as, "Sometimes we get millions of money to do that kind of faulty things, we are being offered. But we never accept, right?" Therefore, in the short term perspective, adherence to the first clause of the code of ethics has not created many positive implications for their entrepreneurial behaviour.

However, their efforts to accomplish the public's safety, health, and welfare have created long-term positive impacts for their entrepreneurial firms. Giving priority to assure the safety in their products/designs/services delivered to the society has created a higher recognition for their firms in the industry over time. Such recognition cannot be achieved within a short period. This was emphasised by engineer $\mathrm{K}$ as "After giving structural plans, we cannot stay in our offices. Sometimes, they do not like to pay for the site visits even. But, free of charge, I visit the sites. Because we have to think about responsibility and safety of the building. But, in the final stage, they understand the value of our visit, instructions and our structural drawings, electrical drawings. Finally, they understand $u s$ and recommend us to others." At first, clients trust these techno-entrepreneurial engineers, and later, the public starts to believe in them as providers of safe engineering and technological solutions. That reputation developed over time has given them many business opportunities and confidence to sustain in the industry as a successful entrepreneur. Entrepreneurial behaviour of need for recognition can be achieved without any extra effort if they ethically prioritise the health, safety and welfare of the public. Holding paramount health, safety and welfare of the public as per the code of ethics of engineers fulfils the technoentrepreneurial engineers' need to serve society. Because making less trouble to society can be identified to serve society while balancing the profits and a sustainable business journey.

\section{Conclusions}

Grounded theory study on how technoentrepreneurial engineers in Sri Lanka adhere to the first clause of IESL code of ethics, i.e., hold paramount health, safety, and welfare of the public, within their entrepreneurial firms established three categories of strategies as a) individual commitments, b) firm-level strategies and c) strategies on community 
outreach. Various strategies grouped under above-mentioned categories can be considered as guidelines for emerging entrepreneurial engineers to adopt. Ten techno-entrepreneurial engineers who participated in this research have mentioned that they have prioritised health and safety in their entrepreneurial firms. Further to that, adherence to the first clause of the IESL code of ethics has supported their entrepreneurial behaviour in long-term perspectives to become successful entrepreneurs rather than getting short term gains in the context of Sri Lanka. The examination of the ethics of entrepreneurial engineers is a relatively novel area of inquiry. Much remains to be studied about this area. However, the contributions made by the current study deliver helpful information for entrepreneurial engineers. This is important because the ability to convert ethics into practice effectively with the client requirements has become progressively significant for longlasting business success.

There are several limitations associated with this study. Since the outcomes of qualitative researches cannot be generalised to a particular context due to its subjective nature [11], the results of this study also cannot be generalised to the overall community of entrepreneurial engineers in Sri Lanka. The sample consisted only of techno-entrepreneurial engineers having charter qualification in Sri Lanka, while no woman entrepreneurial chartered engineer has contributed to this study by sharing her experience due to unavailability. Hence, this study can be considered as eye-opening research in the fields of engineering entrepreneurship and Engineering Ethics. Further studies can be conducted by employing quantitative and qualitative techniques by designing the sample, including the combination of entrepreneurial engineers having chartered and other professional engineering qualifications without a bias in the gender to generate a generalisable result.

\section{Acknowledgement}

The authors wish to pay their gratitude to the techno-entrepreneurial chartered engineers in Sri Lanka who participated in this study voluntarily sharing their valuable experiences.

\section{References}

1. McFadden, C., "25 Richest Engineers in the World."

https:/ / interestingengineering.com/25-richestengineers-world (accessed Jun. 09, 2017).

2. Phan, P. H., "Entrepreneurship Theory: Possibilities and Future Directions," J. Bus. Ventur., Vol. 19, No. 5, pp. 617-620, 2004, doi: 10.1016/j.jbusvent.2003.09.001.

3. Drucker, P. F., Innovation E Entrepreneurship Practice \& Principles. New York: Harper Collins Publishers Inc., 1985.

4. Thiranagama, R. K., “An Empirical Study of Success Factors in Transforming Accounting and Engineering Professionals into Entrepreneurs in the SME Sector, Sri Lanka," NSBM J. Manag., Vol. 1, No. 1, p. 26, 2015, doi: 10.4038/nsbmjm.v1i1.3.

5. Runge, W., Technology Entrepreneurship. Karlsruhe: KIT Scientific Publishing, 2014.

6. Hansen, K. L., and Zenobia, K. E., "C h a p t e r 3," in Civil Engineer's Handbook of Professional Practice, John Wiley \& Sons, Inc, 2011, pp. 63-93.

7. Vitharana, V. H. P., De Silva, G. H. M. J. S., and S. De Silva, "Health Hazards, Risk and Safety Practices in Construction Sites - A Review Study," ENGINEER, Vol. 48, No. 3, pp. 35-44, 2015.

8. Premanathan, T., and Rajini, D., "Occupational Safety and Health hazards of Apparel Sector :Perspective of Northern Province Employees of Sri Lanka," J. Bus. Stud., Vol. 5, No. 1, pp. 26-47, 2018.

9. Department of Community Medicine and U. of C. Faculty of Medicine, "Report on Situational Analysis on Occupational Health and Safety in," 2016. [Online]. Available: http://www.searo.who.int/srilanka/document s/situational_analysis_in_occupational_health_a nd_safety_in_sri_lanka.pdf.

10. "The Institution of Engineers Sri Lanka - Code of Ethics," 2013. http://www.iesl.lk/page1541842.

11. Cresswell, J. W., Research Design, $4^{\text {th }}$ Edition. Los Angeles: Sage Publications, Inc, 2014.

12. Eisenhardt, K. M., "Building Theories from Case Study Research," Acad. Manag. Rev., Vol. 14, No. 4, pp. 532-550, 1989.

13. Whisenhunt, J. L., Chang, C. Y., Flowers, L. R., Brack, G. L., C. O'Hara, and Raines,T. C., "Working with Clients who Self-injure: A 
Grounded Theory Approach," J. Couns. Dev., Vol. 92, No. 4, pp. 387-397, 2014, doi: 10.1002/j.1556-6676.2014.00165.x.

14. Kusumsiri, N., and Jayawardane, A. K. W., "Factors Influencing Success in Fashion Designer Entrepreneurship in Sri Lanka," in National Engineering Conference 2013, 19th ERU Symposium, Faculty of Engineering, University of Moratuwa, Sri lanka, 2013, Vol. 19, pp. 67-74, [Online]. Available: http://www.eru.mrt.ac.lk/web/docs/symposi um/2013/eru201312.pdf.

15. Charmaz, K., Constructing Grounded Theory; A Practical Guide Through Qualitative Analysis, 1st ed. London: SAGE Publications Ltd, 2006.

16. Charmaz, K., "Constructionism and the Grounded Theory Method.," in Handbook of Constructionist Research, J. A. Holstein and J. F. Gubrium, Eds. New York: The Guilford Press, 2008, pp. 397-412.

17. Brosseau, L. M., and Li, S.Y., "Small Business Owners' Health and Safety Intentions: A CrossSectional Survey," Environ. Heal. A Glob. Access Sci. Source, Vol. 4, No. 23, pp. 1-9, 2005, doi: 10.1186/1476-069X-4-23.

18. Aarne Vesilind, P., and Rooke, R. L., "The Engineer shall Hold Paramount the Health, Safety, and Welfare of the Public. Unless, of course...," in International Symposium on Technology and Society, 2001, Vol. 2001-Janua, pp. 162-167, doi: 10.1109/ISTAS.2001.937734.

19. Bhagyani, A., and Kottawatta, H., "Empirical Investigation of Safety Practices in the Large Scale Construction Industry in Sri Lanka," Hum. Resour. Manag. J., Vol. 3, No. 1, pp. 18-32, 2017, doi: $10.31357 /$ hrmj.v3i1.2932.

20. Darshana, W. D., "Improvement of Health and Safety in Construction Sites in Sri Lanka," Eng. J. Inst. Eng. Sri Lanka, Vol. 50, No. 1, pp. 53-70, 2017, doi: 10.4038/engineer.v50i1.7244.

21. Vesilind, P. A., and Gunn, A. S., Hold Paramount: The Engineer's Responsibility to Society, 2nd Editio. Stamford: Cengage Learning, 2011.

22. Coyle, I. R., Sleeman, S. D., and Adams,N., "Safety climate," J. Safety Res., Vol. 26, No. 4, pp. 247-254, 1995, doi: 10.1016/0022-4375(95)00020Q.

23. Chepurenko, A., "Entrepreneurship Theory: New Challenges and Future Prospects," Foresight-Russia, Vol. 9, No. 2, pp. 44-57, 2015, doi: 10.17323/1995-459x.2015.2.44.57. 